\title{
PERENCANAAN STRATEGIS SISTEM INFORMASI DI SEKOLAH TINGGI TEKNOLOGI XYZ PURWAKARTA
}

\author{
${\text { Dede } \text { Irmayanti }^{1)} \text {, Ismi Kaniawulan }}^{2)}$ \\ ${ }^{1,2)}$ Teknik Informatika Sekolah Tinggi Teknologi Wastukancana \\ Email : dedeirmayanti@stt-wastukancana.ac.id ${ }^{1)}$,ismi@stt-wastukancana.ac.id ${ }^{2)}$
}

\begin{abstract}
Abstraksi
Pemanfaatan sistem informasi dan teknologi informasi saat ini mampu menunjang semua aktivitas di semua sektor. Mulai dari pendidikan, pemerintahan, organisasi, dan proses bisnis perusahaan, saat ini hampir semua bidang terutama perusahaan besar menerapkan sistem informasi (SI) dan teknologi informasi (TI) pada perusahaan yang dijalankannya agar dapat mencapai apa yang sudah direncanakan dan diinginkan. Permasalahan yang dihadapi oleh STT XYZ saat ini yaitu dalam pengelolaan data kampus belum optimal dikarenakan kurangnya implementasi sistem informasi dan teknologi informasi yang sesuai dengan kebutuhan kampus, agar dapat mencapai tujuan kampus maka dibutuhkan suatu perencanaan yang sesuai dengan kebutuhan kampus. Metode yang digunakan untuk penelitian ini adalah metode ward and peppard, dengan beberapa alat atau tools yang digunakan yaitu value chain, , SWOT, dan portofolio aplikasi. Hasil dari penelitian ini menghasilkan usulan 16 aplikasi yang terdiri dari 11 sistem baru dan 5 sistem yang harus dikembangkan.
\end{abstract}

\section{Kata Kunci:}

Sistem informasi, ward and peppard, swot, value chain

\begin{abstract}
The use of information systems and information technology is currently able to support all activities in all sectors. Starting from the education, government, organization, and business process of a company, currently almost all fields of large companies use information systems (IS) and information technology (IT) in the companies that run them in order to achieve what has been agreed and desired. The problems caused by STT $X Y Z$ at this time are in the campus data management is not optimal because it involves the implementation of information systems and information technology that is in accordance with campus needs, in order to achieve campus goals, planning is needed in accordance with campus needs. The method used for this research is the environment and peppard method, with several tools or tools used namely value chain, SWOT, and portfolio applications. The results of this study resulted in the support of 16 applications consisting of 11 new systems and 5 systems that must be developed.
\end{abstract}

Keywords:

Information system, ward and peppard, swot, value chain

\section{Pendahuluan}

Perkembangan teknologi informasi dan komunikasi sangat berperan penting dalam sebuah organisasi sebagai penunjang proses bisnis sehingga dapat meningkatkan keunggulan kompetitif dibanding para pesaingnya. Dalam dunia pendidikan, khususnya di lingkungan perguruan tinggi baik negeri maupun swasta, teknologi informasi dan komunikasi berperan penting sebagai penunjang proses kegiatan belajar mengajar dan kegiatan administratif akademik. Selain dalam bidang pendidikan (kegiatan belajar mengajar), perguruan tunggi memiliki tugas penting lainnya yaitu dibidang penelitian dan pengabdian masyarakat.

STT. XYZ merupakan salah satu perguruan tinggi swasta yang berada di wilayah kabupaten Purwakarta. Visi dari STT.XYZ yaitu "Menjadi Perguruan Tinggi berbasis riset terdepan dan pelopor rekayasa teknologi tepat guna di wilayah Purwakarta, Subang dan Karawang”. Dalam upaya mencapai visi dan misi organisasi, STT.XYZ 
setiap periode lima tahun, telah merumuskan rencana strategis yang diharapkan dapat menjadi dasar pencapaian tujuan organisasi, sehingga STT.XYZ dapat lebih unggul dari perguruan tinggi lainnya.

Untuk mencapai suatu keunggulan kompetitif, diperlukan adanya keselarasan antara strategi bisnis dan setrategi SI/TI sehingga penggunaan SI/TI tersebut dapat menunjang proses bisnis yang ada di lingkungan STT.XYZ. Di STT. XYZ saat ini sudah mengimplementasikan penggunaan teknologi informasi dan sistem informasi untuk menunjang proses bisnis. Namun penggunaan SI/TI ini masih belum dilakukan diseluruh bidang maupun proses bisnis. Penggunaan SI/TI hanya sebatas pada proses administrasi akademik, diantaranya perwalian, keuangan, pengelolaan data mahasiswa dan data nilai, e-research untuk pendaftaran judul dan pemilihan dosen pembimbing kerja praktek, TA dan skripsi. Kunci dari keberhasilan institusi pendidikan adalah adanya penerapan sistem informasi untuk pengolahan data institusi secara cepat dan akurat. Institusi pendidikan yang menguasai informasilah yang memiliki keunggulan kompetitif didalam lingkungan makro "regulated free market." [3].

Oleh karena itu, diperlukan sebuah perencanaan strategis sistem informasi dan teknologi informasi dilingkungan kampus STT. XYZ untuk menyelaraskan strategi bisnis dan penggunaan SI/TI. Perencanaan Strategis SI/TI merupakan proses identifikasi portofolio aplikasi SI berbasis komputer yang akan mendukung organisasi dalam pelaksanaan rencana bisnis dan merealisasikan tujuan bisnisnya.

Dari latar belakang tersebut maka dapat diperoleh rumusan masalah yaitu bagaimana membuat sebuah perencanaan strategis sistem informasi di STT XYZ Purwakarta yang selaras dengan visi, misi dan rencana strategis nya.

Tujuan dari penelitian ini yaitu untuk membuat sebuah perencanaan strategis sistem informasi di STT XYZ Purwakarta yang selaras dengan visi, misi dan rencana strategis.

Adapun batasan masalah dalam penelitian ini adalah sebagai berikut:

1. Penelitian ini dilakukan di lingkungan kampus STT XYZ Purwakarta.

2. Pembuatan rencana strategis ini menggunakan metode Ward and Peppard.

3. Tools analisis yang digunakan yaitu, value chain, SWOT, PEST dan Strategic Grid McFarlan.

Manfaat perencanaan strategis sistem informasi [1]:

1. Pengelolaan yang efektif dari aset yang penting dan mahal dari sebuah organisasi.

2. Meningkatkan hubungan dan komunikasi antara bisnis dan organisasi sistem informasi.

3. Menyelaraskan tujuan dan prioritas sistem informasi dengan tujuan dan prioritas bisnis.

4. Mengidentifikasi peluang penggunaan teknologi untuk keunggulan kompetitif dan meningkatkan nilai bagi bisnis.

5. Merencanakan alur dan proses informasi.

6. Efektivtas dan efisiensi dalam mengalokasikan sumber daya sistem informasi.

7. Mengurangi tenaga dan uang yang dibutuhkan selama siklus hidup sistem.

Sebuah perusahaan meraih keunggulan kompetitif dengan menciptakan suatu Rantai Nilai (value chain) yang terdiri dari aktifitas utama dan aktifitas pendukung yang memberikan kontribusi kepada margin. Keunggulan kompetitif dapat direalisasikan dalam hal mendapatkan keunggulan strategis, taktis, maupun operasional. Perencanaan strategis sistem informasi dapat digunakan untuk mengubah arah sebuah perusahaan dalam mendapatkan keunggulan strategisnya [5].

Analisis SWOT (Strengths, Weaknesses, Opportunities, Threats) digunakan untuk menilai kekuatanekuatan dan kelemahan-kelemahan dari sumber daya yang dimiliki oleh organisasi atau perusahaan dan kesempatan-kesempatan eksternal dan tantangan-tantangan yang dihadapi. Analisis internal mengunakan metode SWOT yaitu dengan melihat kekuatan dan kelemahan yang ada didalam perusahaan. Sedangkan peluang dan ancaman adalah faktor yang berasal dari luar perusahaan [2].

\section{Metode Penelitian}

1. Studi Pustaka

Tahapan menambah wawasan atau referensi dari buku-buku, artikel, jurnal dan atau sumber lainnya yang berkaitan dengan perencanaan strategis sitem informasi

2. Observasi

Melakukan pengamatan langsung di STT XYZ Purwakarta dengan maksud untuk mendapatkan data-data yang benar untuk dijadikan acuan dalam pembuatan laporan skripsi.

3. Wawancara

Penulis melakukan wawancara atau Tanya jawab langsung dengan pimpinan dan staf pengelola STT XYZ Purwakarta.

4. Kerangka formulasi strategi dan perencanaan sistem informasi John Ward dan Joe Peppard dapat dilihat pada gambar 1. Tahapan-tahapan pada metode ini meliputi: 1) Analisis lingkungan bisnis internal, 2) 
Vol.4 No.1 Edisi 2020

Analisis lingkungan bisnis eksternal, 3) Analisis lingkungan SI/TI internal dan 4) Analisis lingkungan SI/TI eksternal yang akan menghasilkan rencana strategi SI/TI dan usulan Aplikasi Portofolio [7].

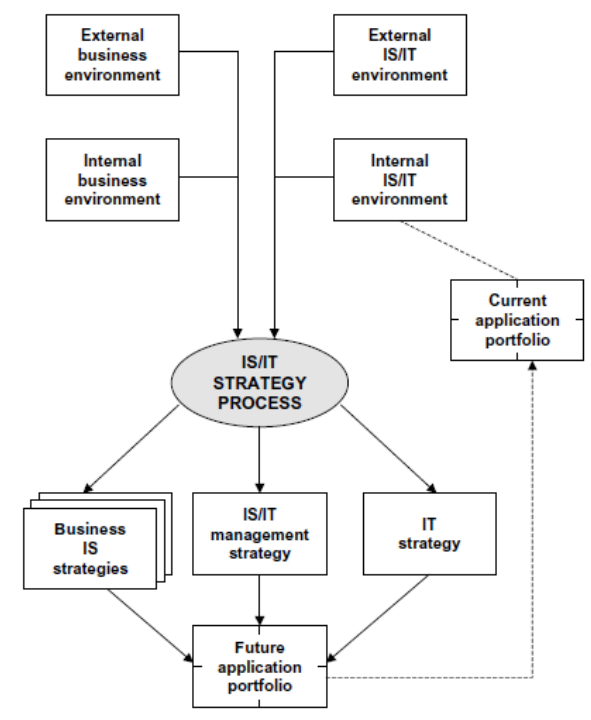

Gambar 1 Metode ward and peppard [7]

\section{Hasil dan Pembahasan}

Untuk melakukan analisis terhadap lingkungan bisnis internal digunakan value chain. Value chain adalah untuk mengidentifikasi aktifitas utama dan aktifitas pendukung yang ada di STT XYZ. Analisis value chain dapat dilihat pada gambar 2 .

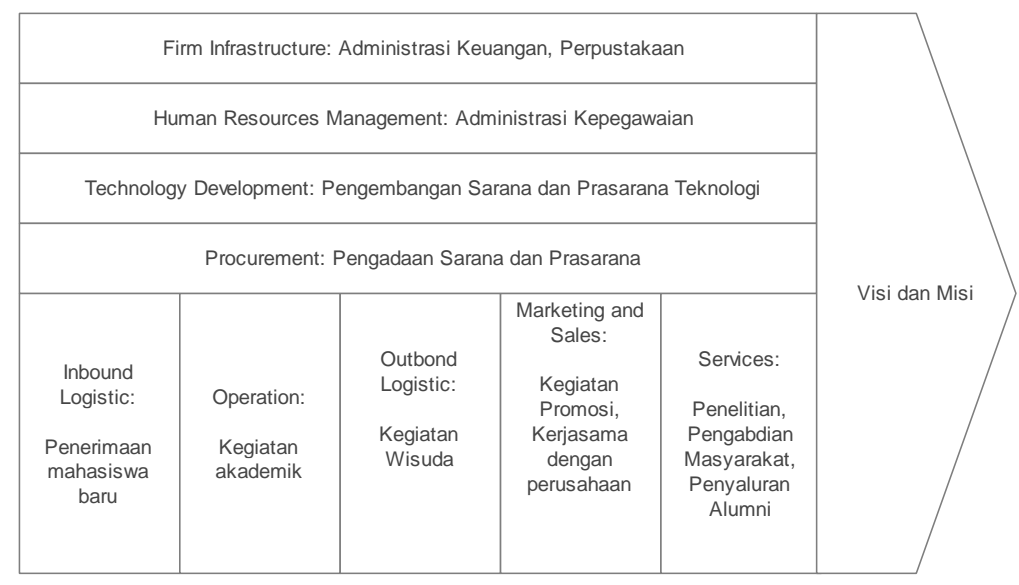

Gambar 2 Analisis Value chain

Dari hasil analisis value chain, kemudian dilakukan identifikasi kebutuhan sistem informasi pada masingmasing aktivitas. Kebutuhan sistem informasi dapat dilihat pada tabel 1.

Tabel 1 Kebutuhan Sistem Informasi

\begin{tabular}{|l|l|l|}
\hline \multicolumn{1}{|c|}{ Aktivitas Utama } & \multicolumn{1}{|c|}{ Bagian / Unit Pelaksana } & \multicolumn{1}{c|}{ Kebutuhan Sistem Informasi } \\
\hline $\begin{array}{l}\text { Kegiatan penerimaan mahasiswa } \\
\text { baru (informasi PMB, } \\
\text { pendaftaran, tes saringan masuk, } \\
\text { pengumuman kelulusan tes, } \\
\text { daftar ulang) }\end{array}$ & $\begin{array}{l}\text { Bidang akademik, bidang } \\
\text { kemahasiswaan, panitia } \\
\text { penerimaan mahasiswa baru, } \\
\text { bidang keuangan }\end{array}$ & $\begin{array}{l}\text { Website untuk penyebaran } \\
\text { informasi }\end{array}$ \\
\hline $\begin{array}{l}\text { Kegiatan akademik (perwalian, } \\
\text { penjadwalan kuliah, perkuliahan, }\end{array}$ & $\begin{array}{l}\text { Sidem informasi } \\
\text { pendaftaran mahasiswa baru } \\
\text { bagian keuangan }\end{array}$ & $\begin{array}{l}\text { Sistem keuangan } \\
\text { Bebsite untuk penyebaran }\end{array}$ \\
\hline
\end{tabular}




\begin{tabular}{|c|c|c|}
\hline $\begin{array}{l}\text { bimbingan kerja praktek dan } \\
\text { tugas akhir, ujian) }\end{array}$ & & $\begin{array}{ll}\text { - } & \text { Sistem informasi akademik } \\
\text { (perwalian, penjadwalan } \\
\text { kuliah, nilai) } \\
\text { - } \quad \text { Sistem keuangan yang } \\
\text { terintegrasi dengan } \\
\text { perwalian } \\
\text { - } \\
\text { Sistem perkuliahan e- } \\
\text { learning } \\
\text { - E-research (bimbingan kerja } \\
\text { praktek dan tugas akhir, } \\
\text { ujian) }\end{array}$ \\
\hline Kegiatan wisuda / kelulusan & $\begin{array}{l}\text { Bidang akademik, panitia } \\
\text { wisuda, program studi, bidang } \\
\text { keuangan }\end{array}$ & $\begin{array}{ll}\text { - } & \text { Website untuk penyebaran } \\
\text { informasi } \\
\text { - } & \text { Sistem informasi lulusan / } \\
\text { tracer study }\end{array}$ \\
\hline $\begin{array}{l}\text { Kegiatan promosi dan kerjasama } \\
\text { dengan lembaga/perusahaan }\end{array}$ & $\begin{array}{l}\text { Bidang akademik, program studi, } \\
\text { lembaga pusat karir }\end{array}$ & $\begin{array}{ll}\text { - } & \text { Website untuk penyebaran } \\
\text { informasi } \\
\text { - } & \text { Sistem informasi } \\
\text { pengelolaan kerjasama } \\
\text { dengan lembaga/perusahaan }\end{array}$ \\
\hline $\begin{array}{l}\text { Kegiatan penelitian, pengabdian } \\
\text { masyarakat dan penyaluran } \\
\text { alumni. }\end{array}$ & LPPM, lembaga pusat karir & $\begin{array}{ll}\text { - } & \text { Sistem informasi untuk } \\
\text { mengelola kegiatan } \\
\text { penelitian dan pengabdian } \\
\text { masyarakat } \\
\text { - } \quad \text { Sistem informasi bursa kerja }\end{array}$ \\
\hline Aktivitas Pendukung & Bagian / Unit Pelaksana & Kebutuhan Sistem Informasi \\
\hline $\begin{array}{l}\text { Administrasi keuangan } \\
\text { (penerimaan dan pengeluaran } \\
\text { keuangan), pengelolaan } \\
\text { perpustakaan (penglolaan buku, } \\
\text { peminjaman dan pengembalian) }\end{array}$ & $\begin{array}{l}\text { Bidang keuangan dan SDM, } \\
\text { bagian perpustakaan }\end{array}$ & $\begin{array}{ll}\text { - } & \text { Sistem informasi keuangan } \\
\text { - } & \text { Sistem informasi penggajian } \\
\text { - } & \text { Sistem perpustakaan }\end{array}$ \\
\hline $\begin{array}{l}\text { Administrasi kepegawaian } \\
\text { (mengelola data kepegawaian) }\end{array}$ & $\begin{array}{l}\text { Bidang keuangan dan SDM, } \\
\text { bagian kepegawaian }\end{array}$ & $\begin{array}{ll}\text { - } & \text { Sistem informasi } \\
& \text { kepegawaian }\end{array}$ \\
\hline $\begin{array}{l}\text { Pengembangan sarana dan } \\
\text { prasarana teknologi }\end{array}$ & $\begin{array}{l}\text { Bagian teknologi informasi, } \\
\text { bidang keuangan dan SDM }\end{array}$ & $\begin{array}{l}\text { - } \begin{array}{l}\text { Sistem informasi } \\
\text { pengembangan sarana dan } \\
\text { prasarana teknologi }\end{array} \\
\end{array}$ \\
\hline Pengadaan sarana dan prasarana & $\begin{array}{l}\text { Bidang keuangan dan SDM, } \\
\text { bagian tata laksana }\end{array}$ & $\begin{array}{l}\text { - } \begin{array}{l}\text { Sistem informasi pengadaan } \\
\text { dan inventarisasi sarana dan } \\
\text { prasarana }\end{array} \\
\end{array}$ \\
\hline
\end{tabular}

Menurut Jogiyanto, analisis SWOT (Strengths, Weaknesses, Opportunities and Threats) yang dilakukan dengan melihat lingkungan bisnis internal dan eksternal untuk mengindetifikasi kekuatan-kekuatan, kelemahankelemahan, kesempatan-kesempatan dan ancaman-ancaman yang ada pada organisasi [4].

Berdasarkan hasil analisis SWOT, selanjutnya akan dilakukan analisis strategi dengan menggunakan Matrix Strategi SWOT. Analisis strategi ini digunakan sebagai dasar untuk merumuskan strategi pencapaian visi, misi dan tujuan kampus. Matrix strategi SWOT dapat dilihat pada tabel 2.

Tabel 2 Matrix Strategi SWOT

\begin{tabular}{|c|c|c|}
\hline & Kekuatan (Strength) & Kelemahan (Weakness) \\
\hline $\begin{array}{l}\text { Peluang } \\
\text { (Opportunities) }\end{array}$ & $\begin{array}{l}\text { (SO) } \\
\text { 1. Melakukan promosi menggunakan } \\
\text { media online untuk meningkatkan } \\
\text { pangsa pasar } \\
\text { 2. Mengembangkan sistem informasi } \\
\text { yang multi platform } \\
\text { 3. Meningkatkan koleksi buku dan } \\
\text { fasilitas di perpustakaan } \\
\text { 4. Membangun sistem informasi } \\
\text { 5embelajaran online }\end{array}$ & \begin{tabular}{ll}
\multicolumn{1}{c}{$($ WO) } \\
1. Meningkatkan akreditasi untuk \\
menambah minat pendaftar \\
2. Menambah saran berupa laboratorium \\
sesuai program studi \\
3. Meningkatkan sistem penjaminan \\
mutu internal \\
4. Merekrut dosen tetap supaya \\
meningkatkan rasio terhadap \\
mahasiswa \\
5. Meningkatkan jabatan akademik
\end{tabular} \\
\hline
\end{tabular}




\begin{tabular}{|c|c|c|}
\hline & Kekuatan (Strength) & Kelemahan (Weakness) \\
\hline & $\begin{array}{l}\text { perusahaan untuk menyalurkan } \\
\text { lulusan }\end{array}$ & $\begin{array}{ll}\text { 6. } & \text { dosen } \\
\text { teknologi } \\
\text { 7. Meningkatkan pendidikan dosen } \\
\text { 8. Meningkatkan paten dan HAKI } \\
\text { 9. Meningkatkan pengelolaan akademik, } \\
\text { keuangan, kepegawaian dan } \\
\text { penggajian }\end{array}$ \\
\hline $\begin{array}{l}\text { Ancaman } \\
\text { (Threats) }\end{array}$ & $\begin{array}{l}\text { Meningkatkan kerjasama dengan } \\
\text { 1. } \begin{array}{l}\text { perusahaan untuk menyalurkan } \\
\text { lulusan }\end{array}\end{array}$ & $\begin{array}{l}\text { (WT) } \\
\text { 1. Melakukan promosi menggunakan } \\
\text { media online untuk meningkatkan } \\
\text { pangsa pasar } \\
\text { 2. Meningkatkan pembelajaran dan } \\
\text { kompetensi mahasiswa } \\
\text { 3. Mendanai penelitian dosen dan } \\
\text { mahasiswa }\end{array}$ \\
\hline
\end{tabular}

Setelah dilakukan anlisis strategi SWOT, selanjutnya dapat diidentifikasikan kebutuhan SI/TI. Solusi SI/TI Matrix SWOT dapat dilihat pada tabel 3.

Tabel 3 Solusi SI/TI Matrix SWOT

\begin{tabular}{|l|l|}
\hline \multicolumn{1}{|c|}{ Strategi } & \multicolumn{1}{c|}{ Kebutuhan SI/TI } \\
\hline Strategi SO & Mengembangkan website sebagai media promosi \\
& Mengembangkan aplikasi mobile \\
& Megembangkan sistem informasi perpustakaan \\
& Mengembangkan sistem e-learning \\
& Mengembangkan sistem informasi pusat karir \\
& Mengembangkan sistem e-research \\
\hline Strategi WO & Mengembangkan sistem pemnajiman mutu \\
& Mengembangkan sistem e-jurnal \\
& Mengembangkan sistem informasi akademik \\
& Mengembangkan sistem informasi keuangan \\
& Mengembangkan sistem informasi kepegawaian \\
& Mengembangkan sistem informasi penggajian \\
& Mengembangkan sistem informasi absensi \\
\hline Strategi ST & Mengembangkan sistem informasi pusat karir \\
& Mengembangkan sistem informasi penerimaan mahasiswa baru \\
\hline Strategi WT & Mengembangkan website sebagai media promosi \\
& Mengembangkan sistem e-learning \\
& Mengembangkan sistem e-jurnal \\
\hline
\end{tabular}

Analisis lingkungan eksternal organisasi dapat dilakukan dengan menggunakan Analisis PEST yang meliputi bidang Politik, Ekonomi, Sosial, Teknologi yang tumbuh dan berkembang. Kemudian akan disusun strategi bisnis untuk menjawab kondisi tersebut [7]. Hasil dari analisis PEST dapat dilakukan identifikasi kebutuhan sistem informasi di STT. XYZ Purwakarta.

1. Politik

a. Sistem informasi akademik yang terintegrasi dengan aplikasi Feeder.

b. Sistem informasi penjamin mutu.

2. Ekonomi

a. Sistem informasi yang dapat memberikan informasi mengenai biaya kuliah dan beasiswa.

3. Sosial

a. Sistem informasi yang mampu memberikan informasi kampus.

4. Teknologi

Sistem informasi terpadu. 
Tahapan selanjutnya dilakukan identifikasi lingkungan SI/TI internal dan eksternal yang disimpulkan pada tabel Strategic Grid McFarlan. Strategic Grid McFarlan bertujuan untuk menganalisis suatu aplikasi atau sistem informasi di suatu operasional organisasi/perusahaan berdasarkan kondisi saat ini, kondisi yang direncanakan serta aplikasi-aplikasi yang dianggap berpotensi dalam menunjang bisnis operasional [6].

\begin{tabular}{|c|c|}
\hline Strategic & High Potential \\
\hline - $\quad$ Website STT. XYZ & - E-research \\
\hline $\begin{array}{ll}- & \text { SI Akademik (SIMAK) } \\
- & \text { SI Keuangan (SIMKEU) }\end{array}$ & $\begin{array}{ll}- & \text { Email } \\
- & \text { Microsoft Office }\end{array}$ \\
\hline Key Operational & Support \\
\hline
\end{tabular}

Berdasarkan hasil analisis dengan menggunakan metode ward and peppard dapat disimpulkan kebutuhan sistem informasi yang ada di STT XYZ adalah sebagai berikut.

Tabel 5 Strategic Grid McFarlan untik Sistem Usulan

\begin{tabular}{|ll|ll|}
\hline \multicolumn{2}{|c|}{ Strategic } & \multicolumn{1}{c|}{ High Potential } \\
\hline- & Website STT. XYZ & - & SI Penerimaan mahasiswa baru \\
& SI Eksekutif & - & SI Perpustakaan \\
& & - & E-Learning \\
& - & E-Jurnal \\
& & - & E-Research \\
& & - & SI Penjamin Mutu \\
& & - & SI Pusat Karir \\
- & SI Akademik & - & Wastu Mobile \\
- & SI Keuangan & - & Email \\
- & SI Kepegawaian & - & Microsoft office \\
\hline & SI Penggajian & - & SI Absensi \\
\hline \multicolumn{2}{|c|}{ Key Operational } & & \multicolumn{1}{c|}{ Support } \\
\hline
\end{tabular}

\section{Kesimpulan}

Perencanaan strategis sistem informasi sangat dibutuhkan oleh sebuah organisasi yang dapat dijadikan acuan dalam pengembangan sistem yang dibutuhkan oleh orgnisasi tersebut. Berdasarkan analisis dengan menggunakan metode Ward and Peppard, maka dapat dihasilkan protofolio aplikasi uauslan yang terdiri dari 16 aplikasi (5 aplikasi yang sudah tersedia dan perlu pengembangan dan 11 aplikasi yang diusulkan) diantaranya: Website STT XYZ, Sistem Informasi Eksekutif (SIE), Sistem Informasi Peneriman Mahasiswa Baru (PMB Online), Sistem Informasi Perpustakaan (SIP), E-Learning, E-Jurnal, E-Research, Sistem Informasi Penjamin Mutu, Sistem Informasi Pusat karir, Wastu Mobile, Sistem Informasi Akademik (SIMAK), Sistem Informasi Keuangan, Sistem Informasi Kepegawaian, Sistem Informasi Penggajian, Email, Microsoft Office, dan Sistem Informasi Absensi.

\section{Daftar Pustaka}

[1] Cassidy, Anita. 2006. A Practical Guide to Information System Strategic Palnning Second Edition. New York: Aurebach Publications.

[2] Hutabarat, J., Huseini, M. 2006. Operasionalisasi Strategi. Elex Media Komputindo.

[3] Indrajit, Eko Richardus. 2000. Kumpulan Artikel Manajemen Sistem Informasi dan Teknologi Informasi. STIMIK Perbanas Renaissace Center

[4] Jogiyanto. 2006. Sistem Informasi Strategi untuk Keunggulan Kompetitif. Yogyakarta: ANDI

[5] McLeod dan P.Schell. 2007. Sistem Informasi Manajemen. Jakarta: Salemba Empat

[6] Purwanto, Edi. 2010. Strategic Grid McFarlan. Jakarta.

[7] Ward, John and Peppard, Joe. 2002. Strategic Planning for Information Systems Third Edition. West Sussex: John Wiley and Sons Ltd. 


\section{Biodata Penulis}

Dede Irmayanti, NIDN 0412048703 memperoleh gelar Sarjana Teknik (S.T), Program Studi Teknik Informatika STT XYZ lulus tahun 2010. Tahun 2017 memperoleh gelar Magister Komputer (M.Kom) dari Program Ilmu Komputer STMIK LIKMI Bandung. Saat ini sebagai Staf Pengajar program Sarjana di STT XYZ Purwakarta

Publikasi Karya Ilmiah:

1. Perencanaan Arsitektur Enterprise Sistem Inforasi Disnakersostrans Kabupaten Purwakarta Menggunakan TOGAF; Jurnal Teknologi Rekayasa p-ISSN: 2548-737X e-ISSN: 2548-8678 Vol 3, no.1 Juni 2018.

2. Simulasi reaksi pembentukan molekul kimia menggunakan teknologi augmented reality. Jurnal: Produktif (Jurnal Ilmiah Pendidikan Teknologi Informasi) 3 (1), 23-32. 2019.

3. sistem pendukung keputusan peserta transmigrasi menggunakan metode simple adittive weight. Jurnal: Produktif (Jurnal Ilmiah Pendidikan Teknologi Informasi) 3 (1), 11-21. 2019.

4. metode simple additive weighting dalam sistem pendukung keputusan pemilihan tempat kuliner di kabupaten purwakarta. Jurnal: Piksel (Penelitian Ilmu Komputer Sistem Embedded And Logic) 7 (1), 23-32. 2019.

Ismi Kaniawulan, memperoleh gelar Sarjana Teknik (S.T), Program Studi Teknik Informatika Universitas Kebangsaan Bandung lulus tahun 2000. Tahun 2011 memperoleh gelat Magister Teknik (MT) dari Program Sistem Informasi Institut Teknologi Bandung. Saat ini sebagai Dosen PNS DPK di STT XYZ Purwakarta.

Publikasi Karya Ilmiah:

1. Pengembangan Prototipe Sistem Informasi Geografis Fasilitas Olahraga Berbasis Mobile (Studi Kasus Fasilitas Olahraga Di Kecamatan Purwakarta), Riau Journal Of Computer Science, Vo; 1 No. 1, 2015.

2. Analisis Potensi Pasar dan Perilaku Pelanggan Layanan Online Shop, Jurnal Teknologika, Vo; 5 No 1, 2016

3. Customer Satisfaction Measurement to Online Sales Using Kano Model and Method Service Quality, International Journal of Science and Research (IJSR), Vol 6 Isuuse 3, 2016.

4. Sistem Computer Supported Collaborative Learning untuk peningkatan pembelajaran Siswa, Produktif Jurnal ilmiah Pendidikan Teknologi Informasi, Vol 3 No 1, 2019, Universitas Muhammadiya Tasikmalaya

5. Sistem Manajemen Pengetahuan Forum Dosen Sebagai Sumber Pustaka Kolaborasi, Jurnal Teknologi Informasi dan Ilmu Komputer (JTIIK) Volume 7 Nomor 1, 2020, Universitas Brawijaya Malang 